\title{
Efficacy of thrombolytic agents in the treatment of pulmonary embolism
}

\author{
T. Capstick* and M.T. Henry
}

\begin{abstract}
Recent guidelines recommend bolus-dose alteplase for treating massive pulmonary embolism (PE). However, the safest and most effective treatment is as yet unknown.

In the present study, a meta-analysis of published studies of alteplase infusion, bolus-dose alteplase and streptokinase was performed. The outcome measures were as follows: objective assessment of thrombolysis; all-cause mortality; deaths due to initial PE, major bleeding episodes and recurrent $\mathrm{PE}$; and morbidity.

In total, 26 studies were identified; however, only two comparative studies of alteplase infusion versus either bolus-dose alteplase or streptokinase were found. Meta-analysis revealed no significant difference between the three regimens, but was compromised by a paucity of data. Crude analysis of summated data on thrombolytic efficacy from all studies revealed that alteplase infusion was more effective than bolus-dose alteplase (relative risk (RR): 1.95; 95\% confidence interval $(\mathrm{Cl})$ : 1.19-3.2), whereas streptokinase was more effective than alteplase infusion (RR: 1.27; $95 \% \mathrm{Cl}: 1.09-1.47)$. Alteplase infusion had a lower mortality due to the initial PE than both bolus-dose alteplase and streptokinase (RR: 0.16 ; $95 \% \mathrm{Cl}: 0.05-0.59$ and RR: 0.13 ; $95 \% \mathrm{Cl}: 0.04-$ 0.46 , respectively).

In conclusion, this evidence suggests that the three thrombolytic agents may vary in efficacy. However, large-scale randomised controlled trials are needed to confirm these results.
\end{abstract}

KEYWORDS: Fibrinolysis, pulmonary embolism, streptokinase, thrombolysis, tissue plasminogen activator

D) ulmonary embolism (PE) is a life-threatening condition with an annual incidence of $60-70$ cases per 100,000 of the population and is associated with a 3-month mortality rate of up to $17 \%[1,2]$. Heparin is recommended for patients with an intermediate or high clinical probability of $\mathrm{PE}$, whilst thrombolysis is only recommended for patients presenting with a massive PE causing haemodynamic instability within a 2-week "time window" $[1,3]$.

The indication and rationale for thrombolysis of PE remains debatable as no large-scale randomised controlled trials (RCTs) comparing thrombolytic agents, or thrombolysis and anticoagulation to anticoagulation alone, have been performed [3]. There have only been three small, double-blind, RCTs designed to demonstrate that thrombolysis reduces mortality from PE [4-6]. The smallest of these trials consisted of only eight patients [5], raising the question as to whether thrombolysis policy should be crafted on the basis such a small trial. The largest randomised trial of thrombolysis plus heparin versus heparin alone for acute PE, showed that a 2-h infusion of alteplase reduced soft endpoints, such as the need to escalate in-patient therapy in patients with sub-massive PE, i.e. normal blood pressure and right ventricular dysfunction; however, no mortality benefits were demonstrated in this group [6].

By far the most common thrombolytic drugs that have been used to thrombolyse PE are urokinase, streptokinase and alteplase. Alteplase is currently the recommended drug, since streptokinase may exacerbate hypotension, whilst the preparation of urokinase (available in the UK for unblocking vascular lines) has a dose that is too low for use in PE [1].

The optimal dosing regimen for alteplase in PE has not been elucidated. Alteplase requires the presence of fibrin as a cofactor and is relatively inactive when free in the plasma, in contrast to streptokinase, which works independently of fibrin. Once bound to fibrin clots, alteplase has a short duration of action, with a plasma half-life of 4-5 min [7]. It was originally thought that alteplase must be given as a continuous infusion in order to maintain adequate plasma concentrations at the site of the thrombus in order to cause
AFFILIATIONS

Depts of *Pharmacy, and

${ }^{\#}$ Respiratory Medicine, Leeds

General Infirmary, Leeds, UK.

CORRESPONDENCE

M. Henry

Dept of Respiratory Medicine

Leeds General Infirmary

Great George St.

Leeds LS1 3EX

UK

Fax: 441133926316

E-mail:

michael.henry@leedsth.nhs.uk

Received:

January 092005

Accepted after revision

July 132005 
lysis of the clot; consequently, the initial studies of alteplase in PE used 2-h infusions [8].

More recently, a number of research groups have investigated the use of bolus thrombolysis of a high concentration of a thrombolytic agent over a short duration of time. It is thought that the administration of high concentrations of alteplase overwhelms platelet activator inhibitor (PAI)-1, a factor produced by the endothelium and platelets that inhibits fibrinolysis, rendering negligible any inhibitory effects of PAI-1 on alteplase activity. The prolonged fibrinolysis that occurs, despite no detectable drug in the plasma, is thought to be as a result of the continuing activity of alteplase directly at the site of the thrombus. In a canine model of PE, administration of $1 \mathrm{mg} \cdot \mathrm{kg}^{-1}$ alteplase over $15 \mathrm{~min}$ resulted in a more rapid initial thrombolysis than a 90 min infusion, although the total lysis was equivalent in both groups [9].

The 2003 British Thoracic Society (BTS) guidelines make the recommendation that "should cardiac arrest occur while in hospital and massive PE is strongly suspected, an immediate intravenous bolus of $50 \mathrm{mg}$ alteplase administered during cardiopulmonary resuscitation may be life saving". However, the same guidelines recommend that an i.v. bolus of $50 \mathrm{mg}$ of alteplase should also be administered to deteriorating patients presenting with massive PE where cardiac arrest is imminent, despite the lack of any published evidence for this course of action [1, 10]. However, the 2004 American College of Chest Physicians guidelines recommended that if alteplase is prescribed for patients who are haemodynamically unstable, a $100 \mathrm{mg}$ infusion over $2 \mathrm{~h}$ should be used [11], which may cause confusion when deciding how to treat massive PE.

\section{METHODS}

All randomised trials for alteplase (as either a $100 \mathrm{mg}$ 2-h infusion or a bolus regimen) and streptokinase in the treatment of PE were sought using the search engines MEDLINE (1966-September 2003), EMBASE (1974-September 2003), CINAHL (1950-September 2003) and the Cochrane Database using the following search terms: "tissue-plasminogen-activator"; "streptokinase"; "thrombolytic-therapy or fibrinolytic-agents"; and "pulmonary-embolism". Although only RCTs would ideally have been included in the review, open and unblinded studies were also included due to the paucity of double-blinded RCTs in this patient group. The reference lists of retrieved articles and published reviews were also searched for further published studies. The outcome measures extracted were objective assessment of thrombolysis, all-cause mortality, death due to initial PE (secondary-totreatment failure), death due to major bleeding episodes, death due to recurrent $\mathrm{PE}$, major bleeding episodes and recurrent PE. Unfortunately, not all data were extractable from all papers. The methodological quality of the included trials was scored using the validated scale by JADAD et al. [12]. This scale consists of three items describing the method of randomisation, blinding and handling of dropouts and withdrawals, and ranges from $0-5$, with higher scores indicating better methodological quality.

A meta-analysis of RCTs was performed using RevMan [13] and a random effects model employed where heterogeneity existed amongst trials, which was tested using the Chi-squared statistic. Initial analysis of these data revealed too few studies and patient numbers to make any definitive conclusions. Therefore, a crude analysis method (a simple summation of data from all published studies, i.e. RCTs, open, retrospective and unblinded) was performed and analysed using RevMan [13].

Three sensitivity analyses were performed to test the robustness of the results and assumptions made in the main metaanalysis. These analyses were used in order to test whether the results were affected by performing the meta-analysis using studies of massive PE only, studies with good methodological quality (score by JADAD et al. [12] of three or more) and also in the crude analysis only, a sensitivity analysis of summated data from RCTs only was also performed. The relative risk (RR), the approximate odds ratio with its corresponding $95 \%$ confidence interval (CI), and a two-tailed p-value were calculated for the overall results. The number needed to treat (NNT) and number needed to harm (NNH) were also indicated when appropriate. The results of each trial were analysed on an intention-to-treat basis.

\section{RESULTS}

\section{Selection and characteristics of included trials}

A total of 15 trials of alteplase [4, 6, 8, 14-25] and 12 trials of streptokinase $[5,21,22,26-34]$ met the inclusion criteria. Although case studies were not included in this review, one exception was made for the report by RUIZ-BAILÉN et al. [35], which was the only source of the BTS recommendation for the use of bolus alteplase in massive PE [1]. In total, there were 406 patients treated with standard alteplase infusions, 323 treated with bolus-dose alteplase and 296 patients treated with streptokinase. However, not all studies reported data for each outcome measure.

The characteristics of the included trials are summarised in tables 1 and 2 . The median (interquartile range) quality score was 2 (1-3). Five studies were double blinded [4, 6, 14, 19, 20], three were single blinded $[8,21,22]$, eight were open randomised trials $[5,16-18,24,28,29,31]$, and nine were prospective or retrospective studies [15, 23, 25-27, 30, 32-34]. Of these, 16 studies were performed only in patients with massive PE $[5,14,15,19,21-27,30-32,34,35]$. The diagnosis of PE was made using the following methods: pulmonary angiography in 16 trials $[8,14,16,17,19,21-24,26-32]$; isotope-perfusion lung scan or pulmonary angiography in seven trials $[4,6,15,18,20,25,33]$; pulmonary angiography, scintigraphy or necroscopy in one case study [35]; and lung perfusion scan only in two trials $[5,34]$. All trials included patients with an onset of symptoms of PE within 14 days of starting treatment, with the exception of two studies where this was not reported $[15,23]$.

Thrombolytic regimens consisted of bolus-dose alteplase in seven trials $[4,15,19,20,23,25,35], 100 \mathrm{mg}$ of alteplase infused over $2 \mathrm{~h}$ in 12 trials $[6,8,14,16-24]$ and streptokinase in 12 trials $[5,21,22,26-34]$. The definitions of major haemorrhage made by the authors of many of the included studies were similar, including intracranial or retroperitoneal haemorrhage, overt bleeding requiring surgical control, blood transfusion, or bleeding causing death. Objectively measured thrombolysis was determined using angiographic evidence 
TABLE 1 Characteristics of the included trials of alteplase

Study [Ref.] Quality score ${ }^{\#} \quad$ Type of study $\quad$ PE severity Patients n $\quad$ Thrombolytic

\begin{tabular}{|c|c|c|c|c|c|c|}
\hline LEVINE et al. [4] & 3 & Double-blind RCT & Nonmassive PE & $\begin{array}{l}33 \\
25\end{array}$ & $\begin{array}{l}0.6 \mathrm{mg} \cdot \mathrm{kg}^{-1} \text { IVB over } 2 \mathrm{~min} \\
\text { Sodium chloride placebo }\end{array}$ & $\begin{array}{l}5000 \text { unit IVB at } t=0 \text { min, then IVI (APTT } \\
1.5-2 \text { ), interrupted only for alteplase }\end{array}$ \\
\hline $\begin{array}{l}\text { KONSTANTINIDES } \\
\text { et al. [6] }\end{array}$ & 5 & Double-blind RCT & Nonmassive PE & 138 & $\begin{array}{l}10 \mathrm{mg} \text { IVB, then } 90 \mathrm{mg} \\
\text { IVI over } 2 \mathrm{~h} \\
\text { Matching placebo: } \\
\text { IVB then IVI over } 2 \mathrm{~h}\end{array}$ & 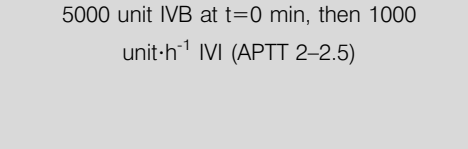 \\
\hline GoLDHABER et al. [8] & 3 & Single-blind RCT & Nonmassive PE & $\begin{array}{l}22 \\
23\end{array}$ & $\begin{array}{l}100 \mathrm{mg} \text { IVI over } 2 \mathrm{~h} \\
\text { Urokinase: } 2000 \text { units } \cdot \mathrm{Ib}^{-1} \\
\text { IVB, then } 2000 \text { units } \cdot \mathrm{lb}^{-1} \cdot \mathrm{h}^{-1} \\
\text { IVI for } 24 \mathrm{~h}\end{array}$ & $\begin{array}{l}\text { IVI when APTT more than twice normal } \\
\text { (dose and APTT range not specified) }\end{array}$ \\
\hline MEYER et al. [14] & 4 & Double-blind RCT & Massive PE & $\begin{array}{l}34 \\
29\end{array}$ & $\begin{array}{l}10 \mathrm{mg} \text { IVB, then } 90 \mathrm{mg} \text { IVI over } 2 \\
\text { Urokinase: } 4400 \text { units } \cdot \mathrm{kg}^{-1} \\
\text { IVB, then } 4400 \text { units } \cdot \mathrm{kg}^{-1} \cdot \mathrm{h}^{-1} \\
\text { IVI for } 12 \mathrm{~h}\end{array}$ & $\begin{array}{l}20 \text { units } \cdot \mathrm{kg}^{-1} \cdot \mathrm{h}^{-1} \mathrm{IVI} \text { at } \mathrm{t}=2 \mathrm{~h} \text { for } 10 \mathrm{~h} \\
20 \text { units } \cdot \mathrm{kg}^{-1} \cdot \mathrm{h}^{-1} \mathrm{IVI} \text { at } \mathrm{t}=12 \mathrm{~h} \text { for } 0-6 \mathrm{~h}\end{array}$ \\
\hline DieHL et al. [15] & 1 & Prospective open & Massive PE & 54 & $\begin{array}{l}1 \mathrm{mg} \cdot \mathrm{kg}^{-1} \text { IVB (range } \\
50-100 \mathrm{mg} \text { ) over } 10 \mathrm{~min}\end{array}$ & 400 units $\cdot \mathrm{kg}^{-1} \cdot$ day $^{-1}$ at $\mathrm{t}=10 \mathrm{~min}$ \\
\hline $\begin{array}{l}\text { GoLDHABER } \\
\text { et al. [16] }\end{array}$ & 2 & Open RCT & Nonmassive PE & $\begin{array}{l}42 \\
45\end{array}$ & $\begin{array}{l}100 \mathrm{mg} \text { IVI over } 2 \mathrm{~h} \\
\text { Urokinase: } 1 \times 10^{6} \text { units IVB } \\
\text { over } 10 \mathrm{~min} \text {, then } 2 \times 10^{6} \\
\text { units IVI over } 110 \mathrm{~min}\end{array}$ & $\begin{array}{c}1050 \text { units } \cdot h^{-1} \text { IVI when APTT more than twice } \\
\text { normal (APTT range not reported) }\end{array}$ \\
\hline $\begin{array}{r}\text { DALLA-VoLtA } \\
\text { et al. [17] }\end{array}$ & 2 & $\begin{array}{l}\text { Open parallel randomised } \\
\text { trial }\end{array}$ & Nonmassive PE & 16 & $\begin{array}{c}10 \mathrm{mg} \text { IVB, then } 90 \mathrm{mg} \mathrm{IVI} \\
\text { over } 2 \mathrm{~h} \\
\text { No treatment }\end{array}$ & $\begin{array}{l}10000 \text { unit IVB at } t=0 \text { min. After thrombolysis } \\
1750 \text { units } \cdot h^{-1} \text { (APTT 2-3) } \\
10000 \text { unit IVB at } t=0 \text { min, then } 1750 \text { units } \cdot h^{-1} \\
\text { (APTT 2-3) }\end{array}$ \\
\hline $\begin{array}{l}\text { GOLDHABER } \\
\text { et al. [18] }\end{array}$ & 3 & Unblinded RCT & Nonmassive PE & 46 & $100 \mathrm{mg}$ IVI over $2 \mathrm{~h}$ & $\begin{array}{c}1000 \text { units } \mathrm{h}^{-1} \text { IVI when APTT more than twice } \\
\text { normal (APTT 1.5-2.5) }\end{array}$ \\
\hline & & & & 55 & No treatment & $\begin{array}{l}5000 \text { unit IVB, then } 1000 \text { units } \cdot h^{-1} \text { IVI } \\
\text { (APTT 1.5-2.5) }\end{array}$ \\
\hline Sors et al. [19] & 4 & Double-blind RCT & Massive PE & 36 & $\begin{array}{l}0.6 \mathrm{mg} \cdot \mathrm{kg}^{-1} \text { IVB over } \\
15 \mathrm{~min}(\max .50 \mathrm{mg})\end{array}$ & $\begin{array}{l}400 \text { units } \cdot \mathrm{kg}^{-1} \cdot \mathrm{d}^{-1} \text { when APTT more } \\
\text { than twice normal (APTT 2-2.5) }\end{array}$ \\
\hline & & & & 17 & $100 \mathrm{mg}$ IVI over $2 \mathrm{~h}$ & \\
\hline $\begin{array}{l}\text { GoLDHABER } \\
\text { et al. [20] }\end{array}$ & 4 & Double-blind RCT & Nonmassive PE & $\begin{array}{l}60 \\
27\end{array}$ & $\begin{array}{l}0.6 \mathrm{mg} \cdot \mathrm{kg}^{-1} \text { IVB over } \\
15 \mathrm{~min}(\max .50 \mathrm{mg}) \\
100 \mathrm{mg} \text { IVI over } 2 \mathrm{~h}\end{array}$ & $\begin{array}{l}\left.1280 \text { units }^{-1} \mathrm{~h}^{-1} \text { IVI (PTT } 60-85 \mathrm{~s}\right) \text { from } \\
t=0 \text {, interrupted only for alteplase }\end{array}$ \\
\hline Meneveau et al. [21] & 2 & $\begin{array}{l}\text { Single-blind randomised } \\
\text { trial }\end{array}$ & Massive PE & 25 & $\begin{array}{l}10 \mathrm{mg} \text { IVB, then } 90 \mathrm{mg} \text { IVI } \\
\text { over } 2 \mathrm{~h} \\
\text { Streptokinase: } 250000 \text { units } \\
\text { IVB over } 15 \mathrm{~min} \text {, then } 100000 \\
\text { units } \cdot \mathrm{h}^{-1} \mathrm{IVI} \text { for } 12 \mathrm{~h}\end{array}$ & $\begin{array}{r}5000 \text { units IVB at } \mathrm{t}=0 \mathrm{~min} \text {, then } 20 \text { units } \cdot \mathrm{kg}^{-1} \cdot \mathrm{h}^{-1} \\
\text { IVI (APTT 2-3) } \\
10 \text { units } \cdot \mathrm{kg}^{-1} \cdot \mathrm{h}^{-1} \text { IVI from } \mathrm{t}=12 \mathrm{~h} \\
\text { (APTT 2-3) }\end{array}$ \\
\hline Meneveau et al. [22] & 2 & Single-blind RCT & Massive PE & $\begin{array}{l}23 \\
43\end{array}$ & $\begin{array}{c}10 \mathrm{mg} \text { IVB, then } 90 \mathrm{mg} \mathrm{IVI} \text { over } 2 \mathrm{~h} \\
\text { Streptokinase: } 1.5 \times 10^{6} \text { units } \\
\text { IVI over } 2 \mathrm{~h}\end{array}$ & 1000 unit $^{-1} \mathrm{~h}^{-1}$ IVI (APTT 2-3) at $\mathrm{t}=2 \mathrm{~h}$ \\
\hline MEYER et al. [23] & 1 & Retrospective study & Massive PE & $\begin{array}{l}19 \\
61 \\
52\end{array}$ & $\begin{array}{c}100 \mathrm{mg} \mathrm{IVI} \text { over } 2 \mathrm{~h} \\
1 \mathrm{mg} \cdot \mathrm{kg}^{-1} \text { over } 10 \mathrm{~min} \\
0.6 \mathrm{mg} \cdot \mathrm{kg}^{-1} \text { over } 10 \mathrm{~min}\end{array}$ & 500 units $\cdot \mathrm{kg}^{-1} \cdot 24 \mathrm{~h}^{-1}$ (APTT 2-3) \\
\hline TeBBE et al. [24] & 2 & $\begin{array}{l}\text { Open parallel randomised } \\
\text { trial }\end{array}$ & Massive PE & 13 & $\begin{array}{l}10 \mathrm{mg} \text { IVB, then } 90 \mathrm{mg} \text { IVI } \\
\text { over } 2 \mathrm{~h} \\
\text { Reteplase: } 10 \text { units IVB } \\
\text { at } \mathrm{t}=0 \text { and } \mathrm{t}=30 \mathrm{~min}\end{array}$ & $\begin{array}{l}70 \text { units } \cdot \mathrm{kg}^{-1} \mathrm{IVB} \text { prior to thrombolysis, } \\
\text { then } 15 \text { units } \cdot \mathrm{kg}^{-1} \cdot \mathrm{h}^{-1} \text { (APTT 2) } \\
70 \text { units } \cdot \mathrm{kg}^{-1} \mathrm{IVB} \text { prior to thrombolysis, } \\
\text { then } 15 \text { units } \cdot \mathrm{kg}^{-1} \cdot \mathrm{h}^{-1} \text { (APTT 2) }\end{array}$ \\
\hline LE ConTE [25] & 1 & Retrospective study & Massive PE & 21 & $\begin{array}{l}0.6 \mathrm{mg} \cdot \mathrm{kg}^{-1} \mathrm{IVB} \text { over } 15 \\
\min (\max .50 \mathrm{mg})\end{array}$ & $\begin{array}{c}400 \text { units } \cdot \mathrm{kg}^{-1} \cdot \text { day }^{-1} \text { when APTT less than } \\
\text { twice normal }\end{array}$ \\
\hline $\begin{array}{l}\text { RuIz-BAILEN } \\
\text { et al. [35] }\end{array}$ & 1 & Case study & Massive PE & 6 & $\begin{array}{l}50 \mathrm{mg} \text { IVB over } 2 \mathrm{~min} \\
\text { at } \mathrm{t}=0 \mathrm{~min} \text {, then } 50 \mathrm{mg} \text { IVB } \\
\text { over } 5 \mathrm{~min} \text { at } \mathrm{t}=30 \mathrm{~min}\end{array}$ & 5000 unit IVB at $t=90 \mathrm{~min}$ \\
\hline
\end{tabular}

PE: pulmonary embolism; RCT: randomised controlled trial; IVB: intravenous bolus; IVI: intravenous infusion; max.: maximum; APTT: activated partial thromboplastin time; PTT: partial thromboplastin time. * : studies assessed using the scale by JADAD et al. [12]; " : alteplase unless otherwise studied. 
of clot lysis in nine studies [8, 16, 17, 26-28, 30-32], cardiac echocardiogram in two studies $[5,18]$ and $>50 \%$ improvement in perfusion lung scan at $24 \mathrm{~h}$ in one study [4]. The follow-up period for recurrent PE was 10 days in two studies $[4,31], 14$ days in three studies [16, 18, 20], 30 days in one study [6], $1 \mathrm{yr}$ in one study [22], and "during hospital stay" in two studies [15, 19]. The follow-up period was not specified in seven studies [14, 17, 21, 26, 29, 34, 35], whilst it was not reported if recurrent $\mathrm{PE}$ was tested for in 10 studies [5, 8, 23-25, 27, 28, 30, 32, 33].

TABLE 2 Characteristics of the included trials of streptokinase

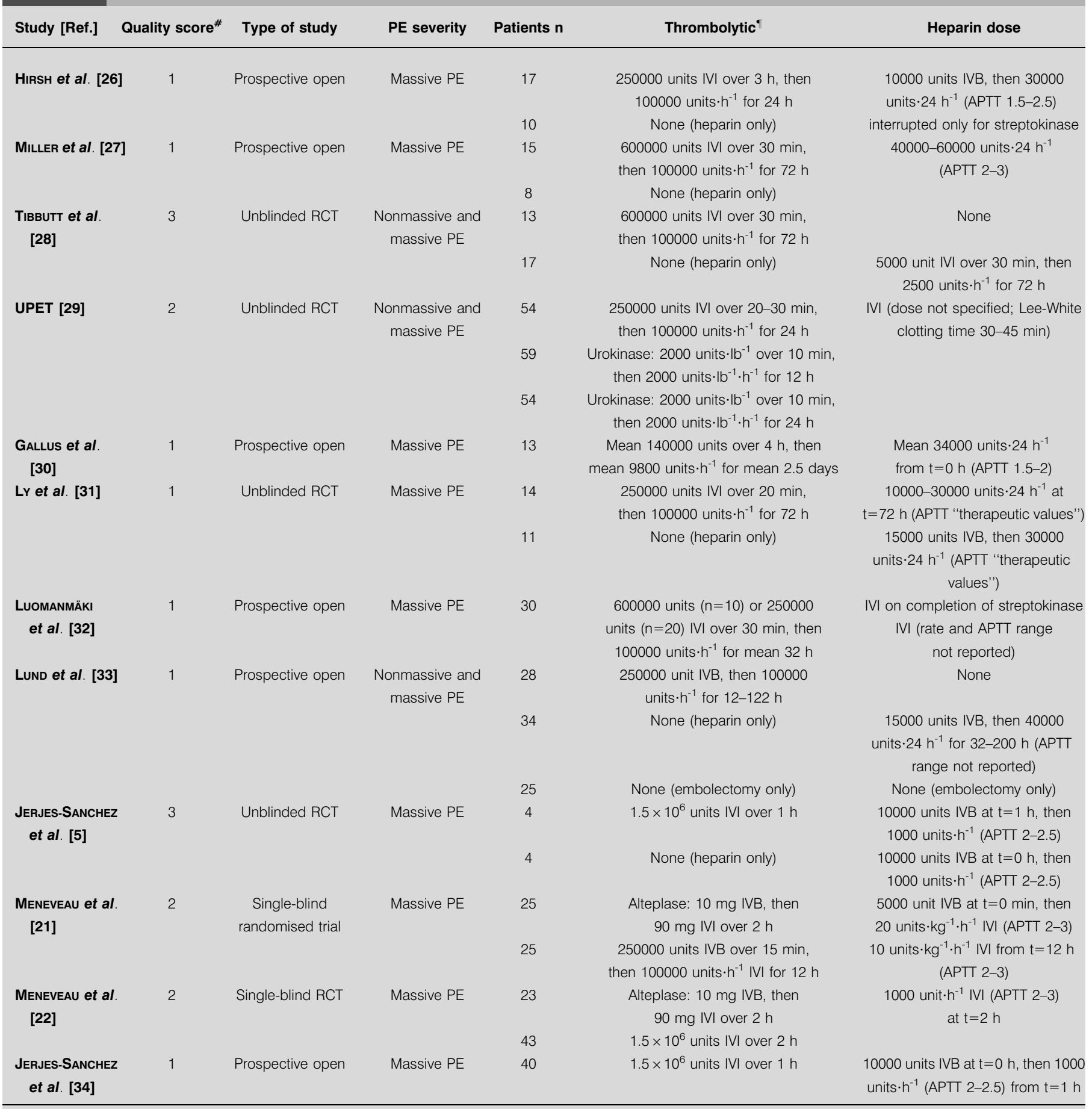

PE: pulmonary embolism; RCT: randomised controlled trial; IVI: intravenous infusion; IVB: intravenous bolus; APTT: activated partial thromboplastin time; UPET: Urokinase-Streptokinase Embolism Trial. *: studies assessed using the scale by JADAD et al. [12]; ": streptokinase unless stated otherwise. 


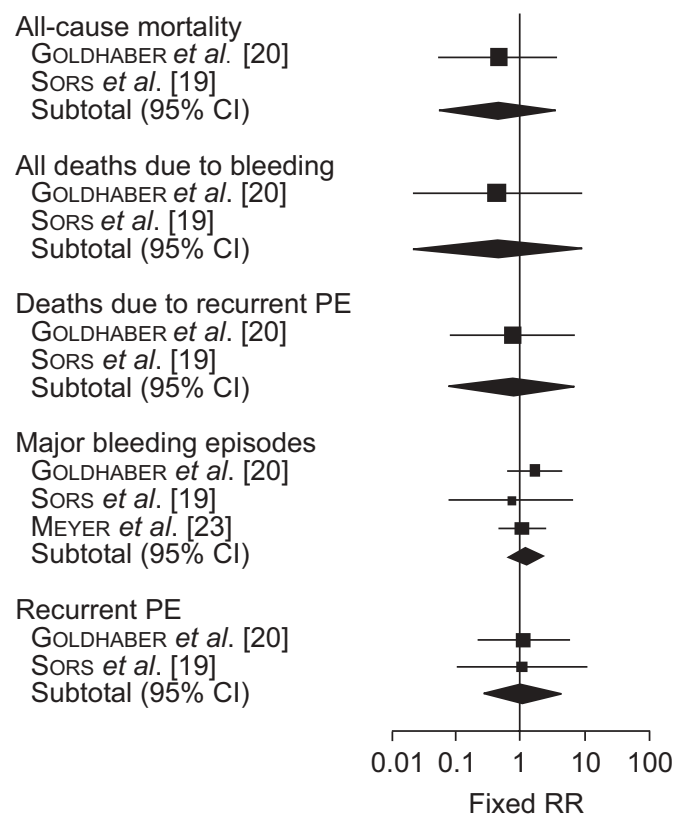

FIGURE 1. Meta-analysis comparing the use of alteplase infusions with bolusdose alteplase in the treatment of massive pulmonary embolism (PE) in different studies or subcategories. Data are presented as relative risk (RR) where 1-100 favours bolus and 0.01-1 favours infusion. $\mathrm{Cl}$ : confidence interval

\section{Meta-analysis}

A meta-analysis comparing the safety and efficacy of different thrombolytic therapies was severely restricted by a small number of studies. There are only two comparative studies of alteplase infusion versus bolus-dose alteplase $(n=140)[19,20]$, two of alteplase infusion versus streptokinase $(n=116)[21,22]$ and none of bolus-dose alteplase versus streptokinase.

When comparing alteplase infusion to bolus-dose alteplase (fig. 1; table 3), no significant differences in outcomes were observed between the two treatments. However, neither trial investigated the effect of treatment on objectively measured thrombolysis, and one study (in massive PE) [19] reported no deaths with either intervention, making meta-analysis impossible. The study by GOLDHABER et al. [20] demonstrated a trend towards a lower all-cause mortality rate in patients treated with alteplase infusion, but this was not statistically significant (RR: 0.44; 95\% CI: $0.05-3.62 ; \mathrm{p}=0.45$ ). There was no significant difference between the two treatments in terms of major bleeding episodes and recurrent PE. Sensitivity analysis could not be performed because too few trials were included.

Meta-analysis of the two studies comparing alteplase infusion to streptokinase revealed no significant difference between the two treatments in all-cause mortality, primarily because of only one death in each treatment group (RR: 1.00; 95\% CI:

TABLE 3 Comparison of the use of alteplase infusions with bolus-dose alteplase in the treatment of massive pulmonary embolism (PE)

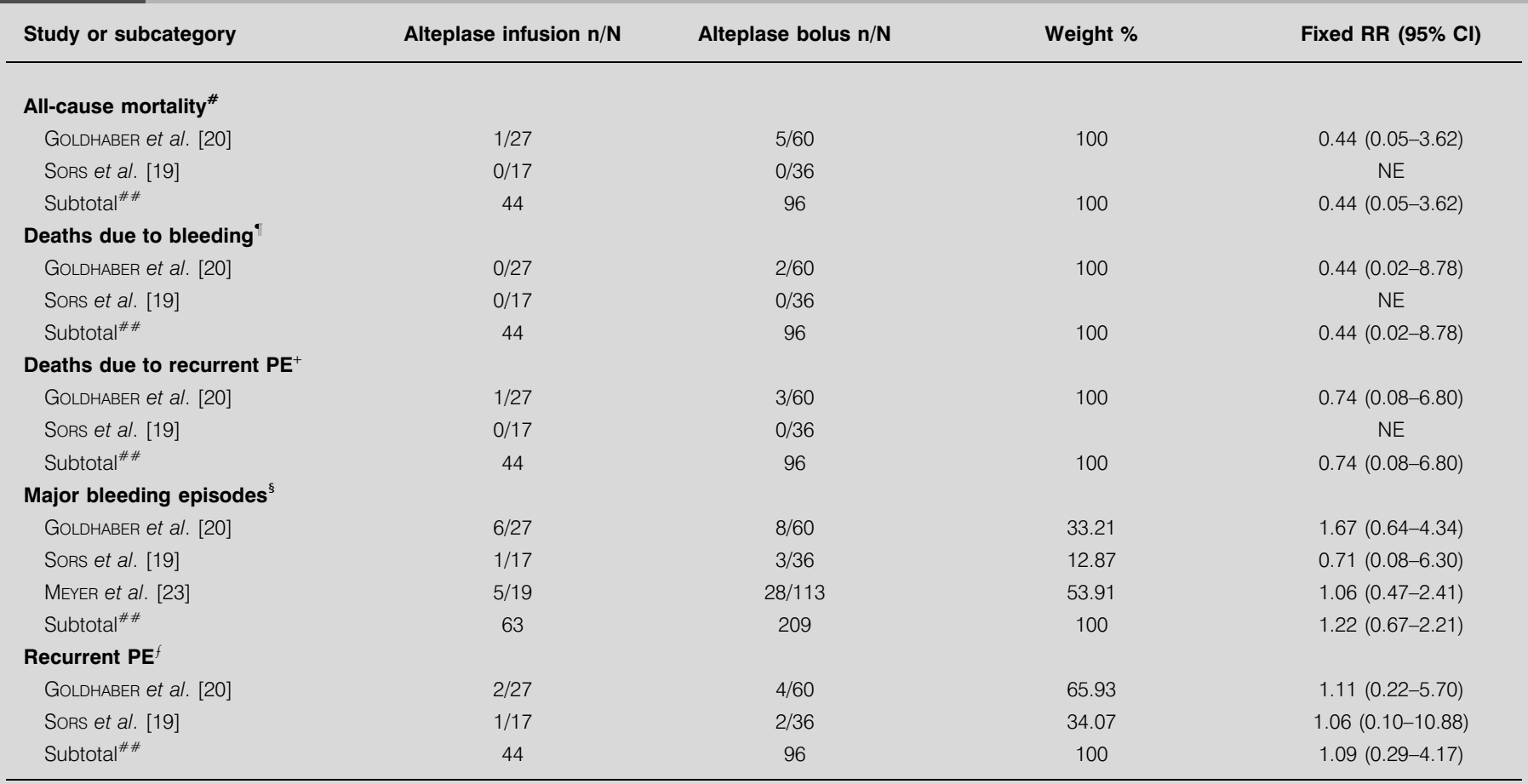

RR: relative risk; Cl: confidence interval; NE: not estimable. ${ }^{\#}$ : total events, 1 (alteplase infusion), 5 (alteplase bolus); test for heterogeneity, not applicable; test for overall effect, $z=0.76, p=0.45$. ": total events, 0 (alteplase infusion), 2 (alteplase bolus); test for heterogeneity, not applicable; test for overall effect, $z=0.54, p=0.59$. ${ }^{+}:$total events, 1 (alteplase infusion), 3 (alteplase bolus); test for heterogeneity, not applicable; test for overall effect, $z=0.27, p=0.79$. ${ }^{s}$ : total events, 12 (alteplase infusion), 39 (alteplase bolus); test for heterogeneity, Chi-squared $=0.76, d f=2(p=0.68), l^{2}=0 \%$; test for overall effect, $z=0.65, p=0.52$. ${ }^{f}$ : total events, 3 (alteplase infusion), 6 (alteplase bolus); test for heterogeneity, Chi-squared $=0.00, d f=1(p=0.97), I^{2}=0 \%$; test for overall effect, $z=0.13, p=0.90 .{ }^{\# \#}: 95 \% \mathrm{Cl}$. 
0.07-15.12; $p=1.0$ ). However, a meta-analysis of these two studies and a retrospective study of haemorrhagic complications of thrombolytic therapy by MEYER et al. [23] demonstrated that alteplase infusion was associated with slightly more major bleeding episodes (RR: 2.07; 95\% CI: 0.8-5.3; $\mathrm{p}=0.13$ ). Sensitivity analysis could not be performed because too few trials were included.

The two studies comparing alteplase infusion to any other treatment (both of which were urokinase), which reported objectively measured thrombolysis $[8,16]$, demonstrated that alteplase infusion is significantly more effective (RR: 1.32; 95\% CI: $1.05-1.67 ; p=0.02)$. Sensitivity analysis could not be performed for this outcome because too few trials were included. Up to eight studies compared alteplase infusion to any other treatment for other outcomes (urokinase $(n=3)$, bolus-dose alteplase $(n=2)$, streptokinase $(n=2)$ and reteplase $(n=1)$; fig. 2; table 4). All-cause mortality was not significantly different between alteplase infusion and other treatments (RR: 1.34; 95\% CI: 0.57-3.14; $\mathrm{p}=0.7)$. Sensitivity analysis was

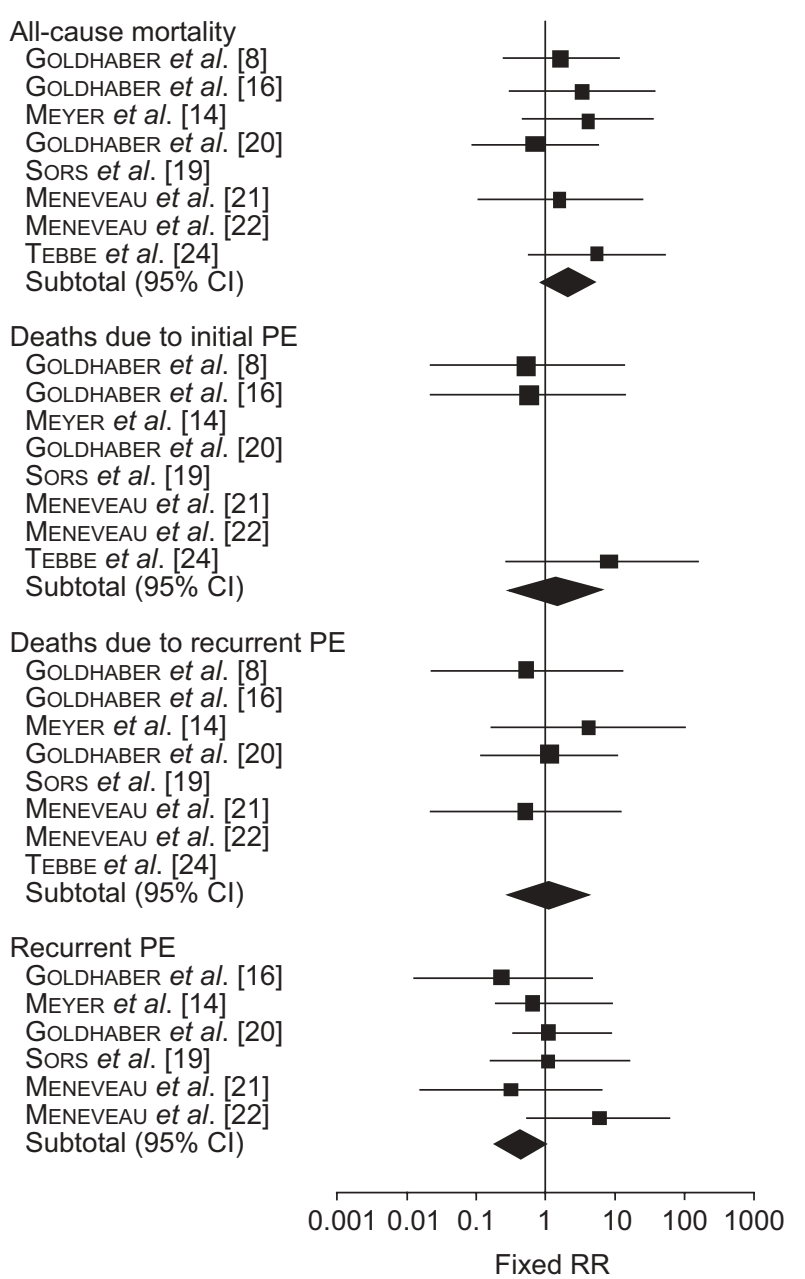

FIGURE 2. Meta-analysis comparing alteplase infusion with all other thromboIytic regimens for the treatment of pulmonary embolism $(\mathrm{PE})$ in different studies or subcategories. Data are presented as relative risk (RR) where 0.001-1 favours alterplase and 1-100 favours others. $\mathrm{Cl}$ : confidence interval. performed for clinical severity of PE and methodological quality, but did not affect the results of the meta-analysis.

\section{Crude analysis of summated data}

Objectively measured thrombolysis

This outcome measure was reported in 12 studies, which included 32 patients treated with bolus-dose alteplase, 125 treated with standard alteplase infusion and 88 treated with streptokinase. The summated results are presented in figure 3. Alteplase infusion achieves clinical thrombolysis in almost twice as many patients as bolus-dose alteplase with a RR of 1.95 (95\% CI: $1.19-3.2 ; p=0.008$ ), equating to a NNT of three (table 5). Similarly, streptokinase achieves clinical thrombolysis in more patients than bolus dose alteplase (RR: 2.48; 95\% CI: 1.52-4.03; $\mathrm{p}=0.0003$ ) and also alteplase infusion (RR: 1.27 ; 95\% CI: 1.09 $1.47 ; p=0.002$ ), equating to a NNT of six. Sensitivity analysis was performed for methodological quality and when only RCTs were included, but did not affect the results of the analysis.

\section{Mortality}

Data were available from 25 studies, including 210 patients treated with bolus-dose alteplase, 387 treated with standard alteplase infusion and 242 treated with streptokinase. The summated results are presented in figure 4. Alteplase infusion was associated with a significantly lower all-cause mortality rate compared with bolus dose alteplase, with a RR of 0.51 (95\% CI: 0.27-0.97; $\mathrm{p}=0.04$; fig. 5; table 6), which was primarily due to a reduction in the number of patients dying as a result of the initial PE (RR: 0.16; 95\% CI; 0.05-0.59; $p=0.005$ ). Similarly, alteplase infusion was associated with a RR of 0.5 (95\% CI: 0.28-0.90; $p=0.02$ ) for death from all cause compared with streptokinase, again primarily due to a reduction in death from the initial PE (RR: 0.13; 95\% CI: 0.04-0.46; $p=0.001$ ). These differences in mortality rates due to the initial PE are equivalent to a $\mathrm{NNH}$ of 25 and 20 if the thrombolytic regimen was switched from alteplase infusions to bolus dose alteplase or streptokinase, respectively (table 5). There was no significant difference in mortality rates in patients treated with streptokinase or bolus-dose alteplase.

Sensitivity analysis did not reveal a significant difference in mortality when the clinical severity of PE, RCT only studies or methodological quality were considered, except for a lower mortality due to initial PE in the analysis of alteplase infusion compared with bolus-dose alteplase $(p=0.04)$ in studies of patients with massive PE.

\section{Major bleeding episodes}

This outcome measure was reported in 24 studies, including a total of 323 patients treated with bolus-dose alteplase, 406 treated with standard alteplase infusion and 225 treated with streptokinase. Data comparing alteplase infusion and bolusdose alteplase are presented in figure 5. Alteplase infusion has a lower risk of major bleeding episodes when compared with bolus-dose alteplase (RR: 0.64; 95\% CI: 0.43-0.96; $\mathrm{p}=0.03$ ) and streptokinase (RR: 0.62; 95\% CI: 0.4-0.96; $\mathrm{p}=0.03$ ). There was no significant difference between the bleeding rates for streptokinase and bolus dose alteplase treatment. Sensitivity analysis could not be performed because too few trials could be included. 
TABLE 4 Comparison of alteplase infusion with all other thrombolytic regimens for the treatment of pulmonary embolism (PE)

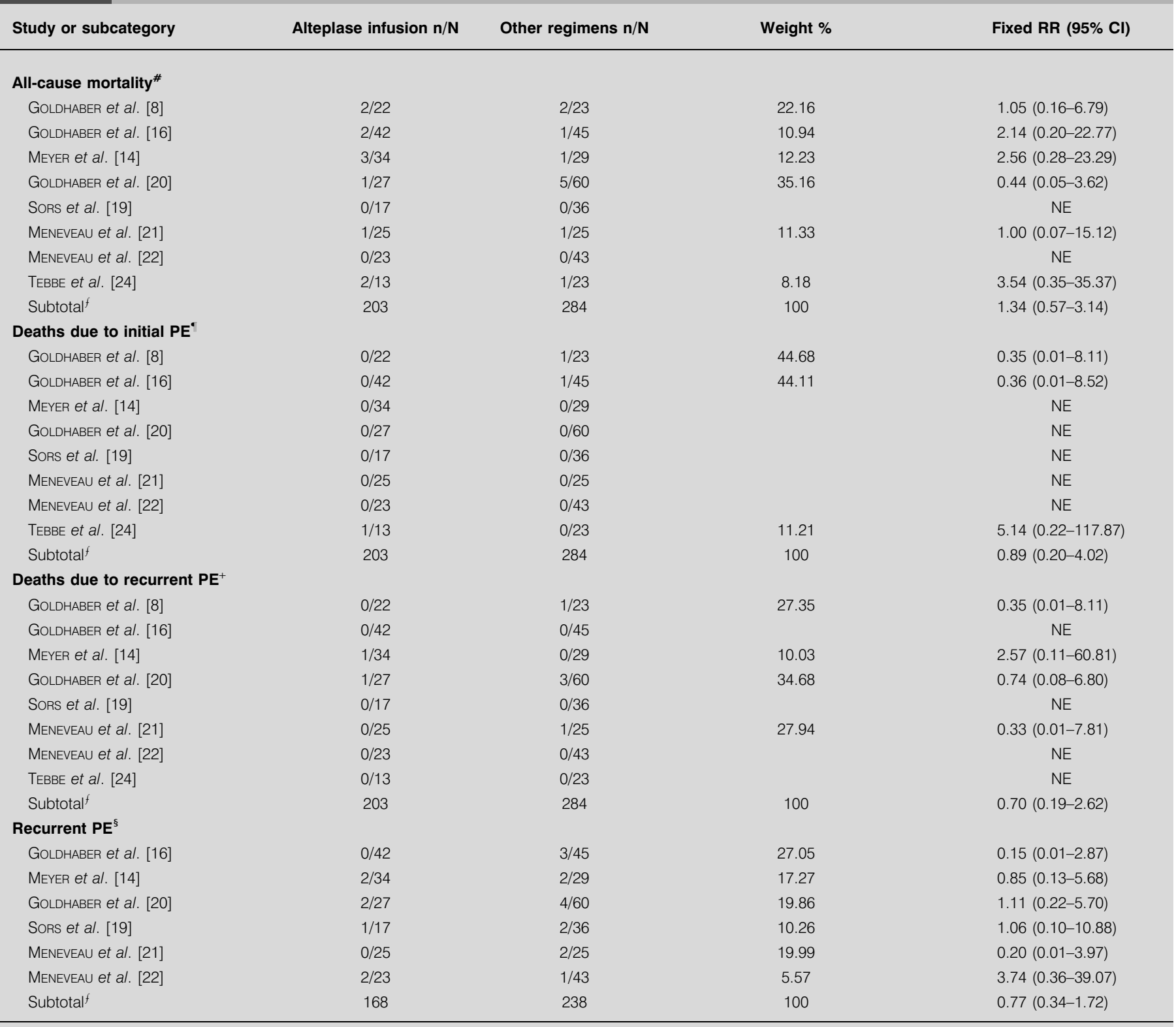

RR: relative risk; $\mathrm{Cl}$ : confidence interval; NE: not estimable. ${ }^{\#}$ : total events, 11 (alteplase infusion), 11 (other regimens); test for heterogeneity, Chi-squared $=2.34$, df $=5$ $(p=0.80), l^{2}=0 \%$; test for overall effect, $z=0.67, p=0.50$. ${ }^{\prime}$ : total events, 1 (alteplase infusion), 2 (other regimens); test for heterogeneity, Chi-squared=1.87, df=2 $(p=0.39), l^{2}=0 \%$; test for overall effect, $z=0.15, p=0.88 .{ }^{+}$: total events, 2 (alteplase infusion), 5 (other regimens); test for heterogeneity, Chi-squared=1.05, df=3 $(p=0.79), I^{2}=0 \%$; test for overall effect, $z=0.53, p=0.60{ }^{s}$ : total events, 7 (alteplase infusion), 14 (other regimens); test for heterogeneity, Chi-squared=3.97, df=5 $(p=0.55), l^{2}=0 \%$; test for overall effect, $z=0.65, p=0.52 .{ }^{f}: 95 \% \mathrm{Cl}$.

\section{Recurrence of PE}

This outcome measure was reported in 15 studies, including a total of 189 patients treated with bolus-dose alteplase, 352 treated with standard alteplase infusion and 179 treated with streptokinase, but was not significantly different between any of the three thrombolytic therapies. Sensitivity analysis could be performed for clinical severity of $\mathrm{PE}$, methodological quality and for RCT only studies, but did not affect the results of this analysis.

\section{DISCUSSION}

Although thrombolysis is now an established treatment for patients with massive PE, the BTS recommendations regarding thrombolysis compared with heparin alone in massive PE are based on one small trial of eight patients where all four patients receiving thrombolysis and heparin survived, whilst all those receiving heparin alone died [5].

In order to determine whether thrombolysis is effective in the treatment of PE, two similar meta-analyses have been 


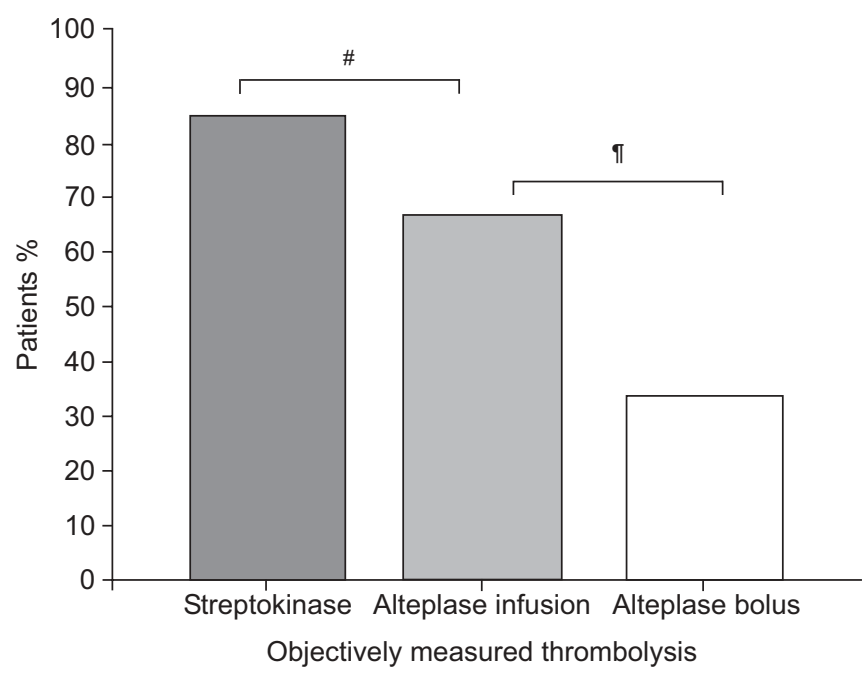

FIGURE 3. Percentage of patients with objectively measured thrombolysis of pulmonary embolism after treatment with thrombolytic agents. ${ }^{*}: 1.27$ risk ratio for streptokinase versus alteplase infusion (Chi-squared test with Yates' correction, $p=0.002) ; '$ ': 1.95 risk ratio for alteplase infusion versus bolus-dose alteplase (Chisquared test with Yates' correction, $p=0.008$ ).

published (neither of which were performed according to Cochrane Collaboration guidelines). THABUT et al. [36] performed a meta-analysis of RCTs comparing any thrombolytic therapy (streptokinase, urokinase or alteplase) and heparin in patients with acute PE of all severities. The authors reported no significant effect on mortality or recurrence of $\mathrm{PE}$, but thrombolysis was associated with an increased risk of major haemorrhage. They concluded that thrombolytic therapy does not appear to have a therapeutic benefit in the management of unselected patients with PE. Similar results were reported by AGNELLI et al. [37], suggesting that thrombolytic therapy should be reserved for patients presenting with massive PE. A third study pooled the results of the two studies $[19,20]$, comparing reduced-dose bolus with full-dose alteplase, but did not perform a meta-analysis of the data [38]. No difference in the safety or efficacy of the two treatment regimens was found. However, the authors commented that, in order for a trial to compare the mortality rates, the study would have required $>800$ patients rather than the total of 140 across the two studies.

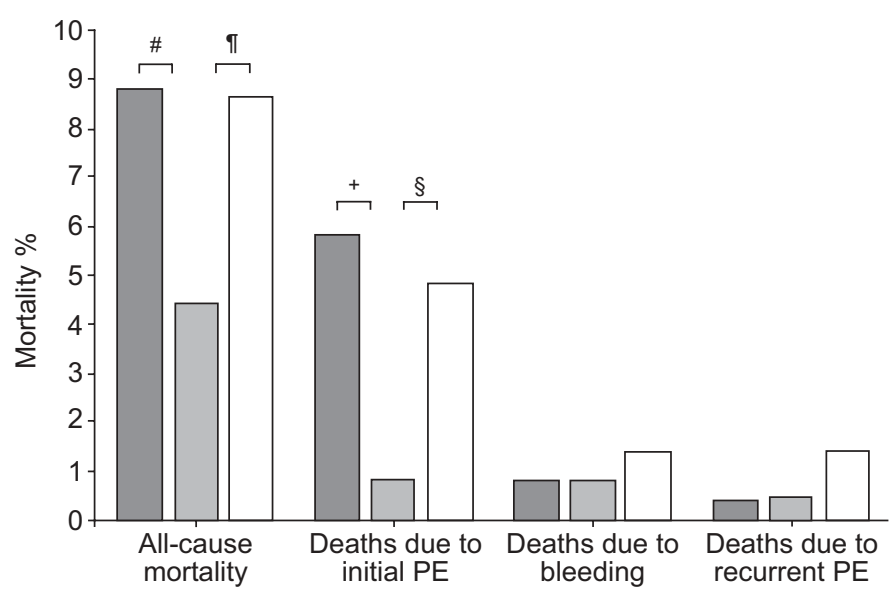

FIGURE 4. Percentage of mortality with thrombolytic drugs ( $\square$ : streptokinase; 匹: alterplase infusion; $\square$ : alteplase bolus). Contributions to mortality associated with initial pulmonary embolism (PE), bleeding and recurrent PE are included. * : 0.5 risk ratio for alteplase infusion versus streptokinase (Chi-squared test with Yates' correction, $p=0.02) ;{ }^{\uparrow}$ : 0.51 risk ratio for alteplase infusion versus bolus-dose alteplase (Chi-squared test with Yates' correction, $p=0.04$ ); ${ }^{+}$: 0.13 risk ratio for alteplase infusion versus streptokinase (Chi-squared test with Yates' correction, $p=0.001) ;{ }^{\S}: 0.16$ risk ratio for alteplase infusion versus bolus-dose alteplase (Chisquared test with Yates' correction, $p=0.005)$.

The aim of the present study was to determine the safest and most effective thrombolytic regimen in patients with PE, in response to the BTS recommendation that bolus-dose alteplase should be used in the treatment of massive life-threatening PE [1]. Meta-analysis of the two published comparative studies of alteplase infusion and bolus-dose alteplase is unable to detect any difference between the two regimens, because of the small patient numbers involved and the fact that neither study investigated the thrombolytic efficacy of either regimen. Similarly, the meta-analysis has also failed to demonstrate any differences in the efficacy of alteplase to streptokinase or to other thrombolytic regimens as a whole. Consequently, overall, the meta-analyses performed have demonstrated that the paucity of published RCTs is still too great to enable adequately powered statistical tests to be performed in order to produce definitive conclusions.

Therefore, in the interest of attempting to provide further guidance for treating patients presenting with massive PE (an area of medicine with no firm evidence-based guidelines), an

\section{TABLE 5 Number needed to harm if thrombolytic regimen switched from alteplase infusion to bolus-dose alteplase or streptokinase ${ }^{\#}$}

\begin{tabular}{|c|c|c|c|c|c|c|c|}
\hline $\begin{array}{l}\text { Change in thrombolytic } \\
\text { regimen }\end{array}$ & $\begin{array}{l}\text { Objectively measured } \\
\text { thrombolysis }\end{array}$ & $\begin{array}{l}\text { All-cause } \\
\text { mortality }\end{array}$ & $\begin{array}{l}\text { Deaths due to } \\
\text { initial PE }\end{array}$ & $\begin{array}{l}\text { Deaths due to } \\
\text { bleeding }\end{array}$ & $\begin{array}{l}\text { Deaths due to } \\
\text { recurrent PE }\end{array}$ & $\begin{array}{c}\text { Major } \\
\text { bleeding }\end{array}$ & $\begin{array}{l}\text { Recurrent } \\
\text { PE }\end{array}$ \\
\hline $\begin{array}{l}\text { Alteplase infusion to } \\
\text { bolus-dose alteplase }\end{array}$ & 3 & 24 & 25 & 167 & 111 & 20 & 200 \\
\hline $\begin{array}{l}\text { Alteplase infusion to } \\
\text { streptokinase }\end{array}$ & -6 & 23 & 20 & 1952 & -966 & 18 & 34 \\
\hline
\end{tabular}

PE: pulmonary embolism. ${ }^{\#}$ : based on crude analysis; ${ }^{\circledR}$ : negative values indicate preference of streptokinase over alteplase. 


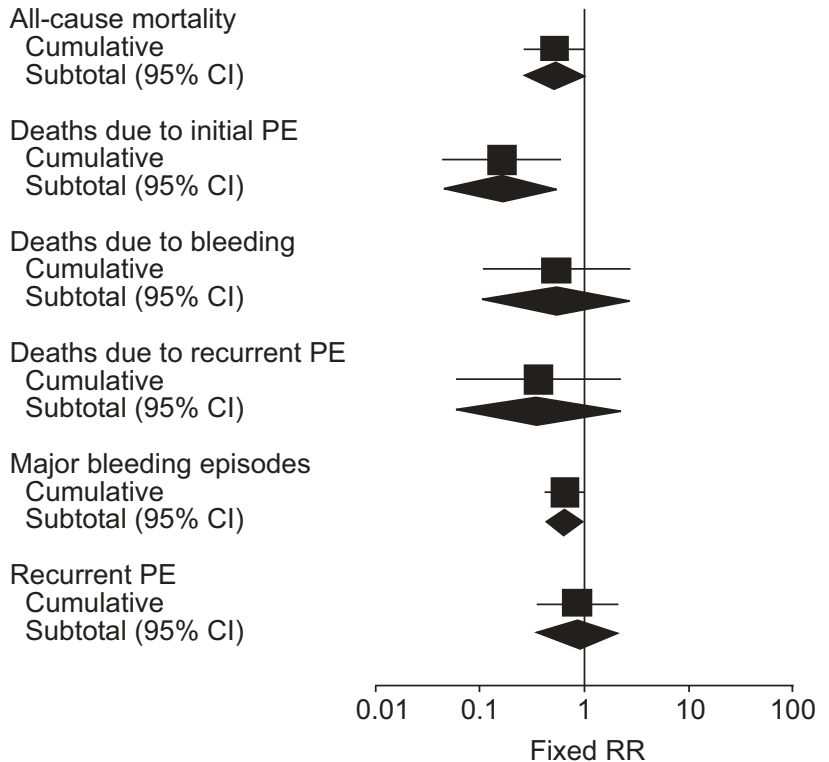

FIGURE 5. Meta-analysis of crude cumulative data comparing morbidity and mortality associated with alteplase infusion versus bolus-dose alteplase in the treatment of massive pulmonary embolism (PE) in different studies or subcategories. Data are presented as relative risk (RR) where $0.01-1$ favours infusion and 1-100 favours bolus. Cl: confidence interval. analysis of the summated data from all the reported trials has been performed. In doing this, the following assumptions have been made. 1) The techniques used to combine data across studies that are not RCTs, placebo controlled or double blinded in patients with different severities are valid. 2) Although the results from study to study were similar, it was assumed that all the studies of standard alteplase infusions, bolus-dose alteplase and streptokinase are homogenous. This may not be valid with the bolus-dose studies, since three different dosages were used in the seven studies. 3) Many of the studies were unblinded, open trials, or retrospective studies, and so there is a risk of bias in the results. 4) Different methods were used to determine the number of patients with objective improvement, e.g. evidence of clot lysis by pulmonary angiography, cardiac echocardiogram or $>50 \%$ improvement in perfusion lung scan at $24 \mathrm{~h}$. Consequently, it was assumed to be appropriate to summate this data in the review. Individual patient data on objective improvement was not provided in 14 studies, thus increasing the risk of making spurious conclusions.

Analysis using this crude method, however, demonstrates that different thrombolytic regimens may not be equivalent, with significant differences in terms of thrombolytic efficacy, allcause mortality, mortality due to the initial PE and major bleeding episodes. In view of these results, the conclusions of previous meta-analyses $[37,38]$ may be queried, as the one

TABLE 6 Comparison of morbidity and mortality associated with alteplase infusion versus bolus-dose alteplase in the treatment of massive pulmonary embolism (PE)

\begin{tabular}{|c|c|c|c|c|}
\hline Study or subcategory & Alteplase infusion $n / N$ & Alteplase bolus $n / N$ & Weight \% & Fixed RR $(95 \% \mathrm{Cl})$ \\
\hline \multicolumn{5}{|l|}{ All-cause mortality ${ }^{\#}$} \\
\hline Cumulative & $17 / 387$ & $18 / 210$ & 100 & $0.51(0.27-0.97)$ \\
\hline \multicolumn{5}{|c|}{ Deaths due to initial PE' } \\
\hline Cumulative & $3 / 387$ & $10 / 210$ & 100 & $0.16(0.05-0.59)$ \\
\hline Cumulative & $3 / 387$ & $3 / 210$ & 100 & $0.54(0.11-2.66)$ \\
\hline Subtotal ${ }^{\pi}$ & 387 & 210 & 100 & $0.54(0.11-2.66)$ \\
\hline \multicolumn{5}{|c|}{ Deaths due to recurrent $\mathrm{PE}^{\S}$} \\
\hline Cumulative & $2 / 387$ & $3 / 210$ & 100 & $0.36(0.06-2.15)$ \\
\hline Subtotal" & 387 & 210 & 100 & $0.36(0.06-2.15)$ \\
\hline \multicolumn{5}{|c|}{ Major bleeding episodes ${ }^{f}$} \\
\hline Cumulative & $13 / 352$ & $8 / 189$ & 100 & $0.87(0.37-2.07)$ \\
\hline Subtotal ${ }^{\bullet}$ & 352 & 189 & 100 & $0.87(0.37-2.07)$ \\
\hline
\end{tabular}

RR: relative risk; Cl: confidence interval. " ${ }^{*}$ : total events, 17 (alteplase infusion), 18 (alteplase bolus); test for heterogeneity, not applicable; test for overall effect, $z=2.04$, $p=0.04$. : total events, 3 (alteplase infusion), 10 (alteplase bolus); test for heterogeneity, not applicable; test for overall effect, $z=2.78, p=0.005 .{ }^{+}:$total events, 3 (alteplase infusion), 3 (alteplase bolus); test for heterogeneity, not applicable; test for overall effect, $z=0.75, p=0.45 .{ }^{s}$ : total events, 2 (alteplase infusion), 3 (alteplase bolus); test for heterogeneity, not applicable; test for overall effect, $z=1.12, p=0.26 .{ }^{f}:$ total events, 38 (alteplase infusion), 47 (alteplase bolus); test for heterogeneity, not applicable; test for overall effect, $z=2.15, p=0.03 .{ }^{\# \#}$ : total events, 13 (alteplase infusion), 8 (alteplase bolus); test for heterogeneity, Chi-squared=0.00, $d f=1$ ( $p=0.97$ ), $\mathrm{I}^{2}=0 \%$; test for overall effect, $z=0.31, p=0.76 .{ }^{~} \%: 95 \% \mathrm{Cl}$ 
major assumption that each thrombolytic agent is as effective as the next may be invalid.

Results from the current crude analysis method suggest that the treatment of patients with PE using alteplase infusions may be more effective than bolus-dose alteplase when the extent of thrombolysis is measured objectively. The NNH of three highlights the fact that a switch in practice from alteplase infusion to bolus-dose alteplase may result in treatment failures. A lower mortality rate was also observed in patients treated with alteplase infusions, as well as a trend towards a lower rate of major bleeding episodes. Thus, alteplase infusion would appear to be the preferred therapeutic thrombolytic regimen in patients presenting with massive PE. However, in situations where cardiac arrest occurs secondary to massive PE, bolus-dose alteplase may be justified in an attempt to ensure that a therapeutic serum level of thrombolytic drug is achieved immediately.

In the crude analysis, the thrombolytic efficacy of streptokinase was shown to be significantly greater than both alteplase regimens, suggesting that it may be the most useful thrombolytic drug. However, this superior thrombolytic efficacy was not associated with a reduction in mortality. In fact, patients treated with alteplase infusions had a significantly lower mortality rate due to the initial PE and a trend in favour of a lower all-cause mortality rate and major bleeding episodes than patients treated with streptokinase. The reason for this paradoxical effect is not clear, but may be a consequence of having a slower onset of action than alteplase [21].

Meta-analysis has failed to demonstrate any significant difference between the thrombolytic regimens of alteplase infusion, bolus-dose alteplase and streptokinase. The failure of the sensitivity analysis to confirm a significant difference in efficacy and safety of thrombolytic regimens when potential study bias was examined may be due to the meta-analysis being underpowered, despite a total of 1,025 patients available for analysis, although not all patients could be included in each analysis. To put into context the extent to which each study is underpowered, it is thought that between 1,000 and 2,000 patients would need to be enrolled into a large-scale randomised clinical trial of thrombolysis versus heparin, depending on estimates of adverse clinical outcomes [39].

In conclusion, whilst the present study may assist in clarifying an area of medicine with a poor evidence base, the use of an unvalidated crude analysis involving the inclusion of small underpowered studies means these results should be interpreted with a certain degree of caution, and a firm recommendation on which thrombolytic agent to use cannot be given, due to the potential lack of statistical power. A largescale randomised, controlled clinical trial is still required to confirm the efficacy of thrombolysis compared with heparin alone in the treatment of pulmonary embolism, but alteplase infusions should be the thrombolytic regimen used in any trial.

\section{REFERENCES}

1 British Thoracic Society Standards of Care Committee Pulmonary Embolism Guideline Development Group. British Thoracic Society guidelines for the management of suspected acute pulmonary embolism. Thorax 2003; 58: 470-484.

2 Goldhaber SZ, Visani L, De Rosa M. Acute pulmonary embolism: clinical outcomes in the international cooperative pulmonary embolism registry (ICOPER). Lancet 1999; 353: 1386-1389.

3 Goldhaber SZ. Thrombolysis in pulmonary embolism: a debatable indication. Thromb Haemost 2001; 86: 444-451.

4 Levine M, Hirsh J, Weitz J, et al. A randomised trial of a single bolus dosage regimen of recombinant tissue plasminogen activator in patients with acute pulmonary embolism. Chest 1990; 98: 1473-1479.

5 Jerjes-Sanchez C, Ramirez-Rivera A, de Lourdes Garcia M, et al. Streptokinase and heparin versus heparin alone in massive pulmonary embolism: a randomized controlled trial. J Thromb Thrombolysis 1995; 2: 227-279.

6 Konstantinides S, Geibel A, Heusel G, et al. Heparin plus alteplase compared with heparin alone in patients with submassive pulmonary embolism. N Engl J Med 2002; 347: 1143-1150.

7 Electronic Medicines Compendium. Datapharm Communications Ltd. http://emc.medicines.org.uk/ Date last accessed: September 23, 2003; Date last updated: October 2002.

8 Goldhaber SZ, Heit J, Sharma GVRK, et al. Randomised controlled trial of recombinant tissue plasminogen activator versus urokinase in the treatment of acute pulmonary embolism. Lancet 1988; 2: 293-298.

9 Goldhaber SZ. Bolus and accelerated thrombolysis: experimental observations and clinical myocardial infarction and pulmonary embolism. Chest 1995; 107: 889-892.

10 Suspected acute pulmonary embolism: a practical approach. British Thoracic Society, Standards of Care. Thorax 1997; 52: Suppl. 4, S1-S24.

11 Büller HR, Agnelli C, Hull RD, Hyers TM, Prins MH, Raskob GE. Antithrombotic therapy for venous thromboembolic disease: the Seventh ACCP Conference on Antithrombotic and Thrombolytic: Therapy. Chest 2004; 126: Suppl. 3, 401S-428S.

12 Jadad AR, Moore A, Carrol D, et al. Assessing the quality of reports of randomised clinical trials: is blinding necessary? Control Clin Trials 1996; 17: 1-12.

13 Review Manager (RevMan). Version 4.2 for Windows. Oxford, England, The Cochrane Collaboration, 2002.

14 Meyer G, Sors H, Charbonner B, et al. Effects of intravenous urokinase versus alteplase on total pulmonary resistance in acute massive pulmonary embolism: a European multicenter double-blind trial. The European Cooperative Study Group for Pulmonary Embolism. J Am Coll Cardiol 1992; 19: 239-245.

15 Diehl JL, Meyer G, Igual J, et al. Effectiveness and safety of bolus administration of alteplase in massive pulmonary embolism. Am J Cardiol 1992; 70: 1477-1480.

16 Goldhaber SZ, Kessler CM, Heit JA, et al. Recombinant tissue-type plasminogen activator versus a novel dosing regimen of urokinase in acute pulmonary embolism: a randomised controlled trial. J Am Coll Cardiol 1992; 20: 24-30.

17 Dalla-Volta S, Palla A, Santolicandro A, et al. PAIMS 2: alteplase combined with heparin versus heparin alone in the treatment of acute pulmonary embolism. Plasminogen 
activator Italian multicenter study 2. J Am Coll Cardiol 1992; 20: 520-526.

18 Goldhaber SZ, Haire W, Feldstein ML, et al. Alteplase versus heparin in acute pulmonary embolism: randomised trial assessing right-ventricular function and pulmonary perfusion. Lancet 1993; 341: 507-511.

19 Sors H, Pacouret G, Azarian R, Meyer G, Charbonnier B, Simonneau G. Hemodynamic effects of bolus vs 2-h infusion of alteplase in acute massive pulmonary embolism: a randomized controlled multicenter trial. Chest 1994; 106: 712-717.

20 Goldhaber SZ, Agnelli G, Levine MN. Reduced dose bolus alteplase vs conventional alteplase infusion for pulmonary embolism thrombolysis: an international multicenter randomized trial. Chest 1994; 106: 718-724.

21 Meneveau N, Schiele F, Vuillemenot A, et al. Streptokinase vs alteplase in massive pulmonary embolism. A randomized trial assessing right heart haemodynamics and pulmonary vascular obstruction. Eur Heart J 1997; 18: 1141-1148.

22 Meneveau N, Schiele F, Metz D, et al. Comparative efficacy of a two-hour regimen of streptokinase versus alteplase in acute massive pulmonary embolism: immediate clinical and hemodynamic outcome and one-year follow-up. J Am Coll Cardiol 1998; 31: 1057-1063.

23 Meyer G, Gisselbrecht M, Diehl JL, et al. Incidence and predictors of major haemorrhagic complications from thrombolytic therapy in patients with massive pulmonary embolism. Am J Med 1998; 105: 472-477.

24 Tebbe U, Graf A, Kamke W, et al. Hemodynamic effects of double bolus reteplase versus alteplase infusion in massive pulmonary embolism. Am Heart J 1999; 138: 39-44.

25 Le Conte P, Huchet L, Trewick D, et al. Efficacy of alteplase thrombolysis for ED treatment of pulmonary embolism with shock. Am J Emerg Med 2003; 21: 438-440.

26 Hirsh J, McDonald IG, Hale GA, O'Sullivan EF, Jelinek VM. Comparison of the effects of streptokinase and heparin on the early rate of resolution of major pulmonary embolism. Can Med Assoc J 1971; 104: 488-491.

27 Miller GAH, Sutton GC, Kerr IH, Gibson RV, Honey M. Comparison of streptokinase and heparin in treatment of isolated acute massive pulmonary embolism. BMJ 1971; 2: 681-684.
28 Tibbutt DA, Davies JA, Anderson JA, et al. Comparison by controlled clinical trial of streptokinase and heparin in treatment of life-threatening pulmonary embolism. BMJ 1974; 1: 343-347.

29 Urokinase-streptokinase embolism trial. Phase 2 results. A cooperative study. JAMA 1974; 229: 1606-1613.

30 Gallus AS, Hirsh J, Cade JF, et al. Thrombolysis with a combination of small doses of streptokinase and full doses of heparin. Semin Thromb Hemost 1975; 2: 14-32.

31 Ly B, Arneson H, Eie H, Hol R. A controlled clinical trial of streptokinase and heparin in the treatment of major pulmonary embolism. Acta Med Scand 1978; 203: 465-470.

32 Luomanmäki K, Halttunen PK, Hekali P, Valle M, Heikkila J. Experience with streptokinase treatment of major pulmonary embolism. Ann Clin Res 1983; 15: 21-25.

33 Lund O, Nielsen TT, Schifter S, Roenne K. Treatment of pulmonary embolism with full-dose heparin, streptokinase or embolectomy-results and indications. Thorac Cardiovasc Surg 1986; 34: 240-246.

34 Jerjes-Sanchez C, Ramirez-Rivera A, Arriaga-Nava R, et al. High dose and short-term streptokinase infusion in patients with pulmonary embolism: prospective with seven year follow-up trial. J Thromb Thrombolysis 2001; 12 : 237-247.

35 Ruiz-Bailén M, Aguayo-de-Hoyos E, Serrano-Córcoles MC, et al. Thrombolysis with recombinant tissue plasminogen activator during cardiopulmonary resuscitation in fulminant pulmonary embolism. A case series. Resuscitation 2001; 51: 97-101.

36 Thabut G, Thabut D, Myers RP, et al. Thrombolytic therapy of pulmonary embolism: a meta-analysis. J Am Coll Cardiol 2002; 40: 1660-1667.

37 Agnelli G, Becattini C, Kirschstein T. Thrombolysis vs heparin in the treatment of pulmonary embolism: a clinical outcome-based meta-analysis. Arch Intern Med 2002; 162 : 2537-2541.

38 Goldhaber SZ, Feldstein ML, Sors H. Two trials of reduced bolus alteplase in the treatment of pulmonary embolism. An overview. Chest 1994; 106: 725-726.

39 Goldhaber SZ. Thrombolysis in pulmonary embolism: a large-scale clinical trial is overdue. Circulation 2001; 104: 2876-2878. 